\title{
Impact of Non-farm Activities on Wellbeing of Rural Household, the Case of Kersa District, Eastern Hararghe Zone, Ethiopia
}

\author{
Fami Abdurezak ${ }^{1,}$, Adinan Ahmed ${ }^{2}$ \\ ${ }^{1}$ Department of Agricultural Economics, Bonga University, Bonga, Ethiopia \\ ${ }^{2}$ Department of Rural Development and Agricultural Extension, Bonga University, Bonga, Ethiopia
}

Email address:

abdurezakfami@gmail.com (F. Abdurezak)

${ }^{*}$ Corresponding author

To cite this article:

Fami Abdurezak, Adinan Ahmed. Impact of Non-farm Activities on Wellbeing of Rural Household, the Case of Kersa District, Eastern Hararghe Zone, Ethiopia. Humanities and Social Sciences. Vol. 8, No. 6, 2020, pp. 182-190. doi: 10.11648/j.hss.20200806.13

Received: September 19, 2020; Accepted: September 30, 2020; Published: November 19, 2020

\begin{abstract}
The study evaluated impact of non-farm activities on wellbeing of rural household using cross-sectional data. Household's consumption expenditure per adult equivalent was analyzed to measure household wellbeing. Multi-stage sampling technique was employed to select sample households from three Kebeles. Both primary and secondary data were used. Data were collected primarily through Semi-structured survey questionnaire from 178 households. Descriptive statistics and propensity score matching model were used to analyze the data. Propensity score matching (PSM) technique of impact evaluation preferred to overcome counterfactual problem and selection bias. Analysis results show that non-farm activities have increased consumption expenditure per adult equivalent ranging from $29.1 \%$ to $36.7 \%$ for participant households. In conclusion, participant households were more likely to be wellbeing as compared to the non-participant households. The result from the logistic estimator also revealed that participation in non-farm activities was significantly associated with variables such as age, education, adult equivalent size, cultivable land size, farm experience, and distance from main road, tropical livestock unit and access to nonfarm training. Therefore, such rural development planners and other stakeholders should consider the roles of these variables within the selection of participants for desired impact on economic wellbeing.
\end{abstract}

Keywords: Non-farm Activities, Impact, Propensity Score Matching, Wellbeing

\section{Introduction}

Agriculture is the most economic sector within the developing country. The livelihoods of Most Africa's poor depend largely on agriculture [1], specifically in sub-saran African; agriculture contributes large percentage of GDP and generation of employment [2]. Despite the agriculture remains the most source of livelihood within the developing country, production is far from being adequate. The reason is that Agricultural sector growth in Africa has not been advanced [3]. Agricultural productivity in developing country is affected by various factors like climate change, based on rain fed, Prevalence of backward agricultural practices. As study with [4] agricultural productivity remain stagnant in sub-Saharan Africa. Additionally, smallholder farmers in developing countries are affected by climate change and variability adversely [5]. As a result, farmers are taking up various altered copy strategies to reduce the vulnerability of farming output. From this strategies farmers in sub Saharan Africa participate in livelihood diversification activities to enhance their living standards through increasing households income accumulation and preserve their livelihoods facing faraway from increasing hazards of climatic and economic $[6,7]$.

Moreover, Farming alone has failed to assure sufficient livelihood for most rural farming households in developing countries. Africa remains the continent with the highest prevalence of food security problems, with around one in four of its people estimated to be food insecure [8]. From African country specifically sub-Saharan Africa has the highest occurrence of food insecure people [9]. This implies sub-Saharan Africa is the lowest level of wellbeing because 
food security and consumption is one indicators of wellbeing. As study with [10] food security and consumption are the indicators of wellbeing. For this reason non-farm works could be a pathway for improving the economic wellbeing of farm households in rural areas of developing countries [10]. So as to boost wellbeing of society, engaging in non-farm activities are ongoing that contributes $35-50 \%$ income from [11]. Therefore, expansion of non-farm rural activities and diversification of income are desirable policy objectives since they offer individuals and households more options to get better their livelihood security and living standards [12]. Thus, not possible to achieve the goal of reducing poverty without participating in non-agricultural activities like offfarm and non-farm activities [13].

Agriculture sector is the mainstay of Ethiopian economy contributing about 43 percent of Gross Domestic Product, 70 percent of foreign exchange earnings and 84 percent of the population living in the rural areas depends on agriculture for livelihood [14]. Even though agriculture is the engine of Ethiopian economy and means of livelihood for the majority of the population, its performance remained underdeveloped by various factors that is responsible for the low productivity of the farming sector in Ethiopia. As [15] reported that even if the sector contributes to the growth of economy, it faces multitude challenges. Among the main challenges that leads for landholding fragmentation and reduction of productivity is unexpected population growth [16].

According to [17] Ethiopia is the second most populous country in Africa with a population around 109 million people in 2018 and their living standards of households are very low. As reviewed by [18] in Ethiopia there have been only $27 \%$ of small holders were participated in non-farm or off farm economic activities while major of the population has been employed in food production; it couldn't address problems with food insecurity. As a result, Ethiopia is one of the most foods insecure and famine affected countries [19]. Around $40 \%$ of Ethiopian households for whom their majority reside in rural parts of the country were food insecure and undernourished by using the threshold of 2,550 kcal per adult equivalent per day [20].

There are several factors that could be cause for food insecurity in Ethiopia. The major causes of the food insecurity in Ethiopia are natural disasters, population growth, land fragmentation and environmental degradation and limited capacity of infrastructure [21, 22]. As indicated in [23] over half of Ethiopian smallholder farmers operate less than one hectare. And also quite half household in Ethiopia cultivate less than one hectare of land while average household size is approximately five members [24]. As a result Ethiopia is one of the poorest countries with a percapita income of USD790 and about $25 \%$ of the population lives below the poverty line with around 31 million people considered undernourished [17]. And also those who use agriculture as a livelihood activity were faced by food insecurity [25]. Consistent with [26] quite $41 \%$ of the Ethiopian population lives below the poverty line and above 31 million people are undernourished. Consequently, a problem with agricultural productivity with increasing population growth is a critical bottleneck to the wellbeing of rural households in Ethiopia specifically in study area. So in order to tackle the trouble or risk with agricultural efficiency some of rural households are engaging in a variety of nonfarm activities to diversify their income with view to boost their welfare in study area.

To address the matter associated with agriculture activities, Non-farm activities are an alternative opportunities to reduce problem with agricultural production [27, 28]. The Government also launched a different policy and strategies to alter the living standard of Ethiopian population in terms of giving more attention on expanding non farm sector. As a result of this initiative, policy towards infrastructural development in rural areas can facilitate the transformation of the rural economy goals explicitly stated in the government's Growth and Transformation Plan [29]. Hence, promotion of non-farm activities is being considered as a promising facilitator of development by Ethiopian government, as manifested within the Plan for Accelerated and Sustainable Development to end Poverty [30].

Furthermore, one of different strategies to pathway out of poverty and food insecurity to realize wellbeing is engaging in non-farm activities. Non-farm is beneficial to mitigate economic and environmental risks and to improve livelihood sustainability and regional sustainable development. As signify in study of [31] one important pathway towards sustainable livelihoods for the smallholder farmers living with marginal environments involves the avoidance of longterm dependency on one income source alone. Accordingly, Non-farm activity is widely considered as a vital basis to empower economically weak smallholder farmers by enhancing purchasing power of goods and thereby reduces the constraints that they face in the market. The economic wellbeing of households improved through non-farm enterprise [32]. In several researches wellbeing was showed as an availability and economic access to fulfill basic needs and heath care $[33,34]$. Non-farm activities provide additional income that enables farmers to purchasing power and expend on their basic needs include food, education, clothing and health care [33]. This implies that non-farm activities play a great role in maintaining wellbeing of households. Therefore, So as to handle the problem with food security encouraging nonfarm activity is one of an alternative strategy [35]. Similarly in study of [36] So as to improve household income and achieve food self-sufficiency promotes non-agricultural activities play a significant role.

Currently, there's a growing evidence that rural households in Ethiopia are participated in diverse livelihood strategies faraway from purely crop and livestock production towards non-farm and off-farm activities that are undertaken to broaden and generate additional income for survival and deal with different livelihood shocks, trends, and seasonality related to agricultural production [13, 37]. In Ethiopian people recognizing the importance of non-farm activities and that they are inspiring for participate in nonfarm employment and generates $33 \%$ of income generate from it [38]. And also 
within highland of eastern Hararghe around $60 \%$ percentage of household participated in non-farm activities for enhancing farmer livelihood and reducing rural poverty [39].

The evaluation of this study take into consideration to reduce limitation within previous studies regarding non-farm activities that has varying results and procedural shortfalls in east Hararghe zone. As an example study by [39] analyzed factor affecting participation in non-farm activities, from this analysis education was insignificant. [40] Who conducted study at eastern Hararghe zone used data only for identified types of non-farm activities and role of it in income generation through descriptive statistics. Additionally, Even though prior some related works are done on determinant participation of small-scale farmers in non-farm activities at country level, still there aren't any empirical findings that are available on the impact of non-farm activities on well-being in study area. Therefore, the target of this study is to evaluate the impact nonfarm activities on household wellbeing for the selected study area. To accomplish objective of the study
Propensity score matching method was employed.

\section{Methodology}

\subsection{Background of Study Area}

The study was conducted in Kersa (Qersa) district which is found in Eastern Hararghe zone of Oromia regional state, Eastern Ethiopia. According to [41] report that Kersa Woreda is located at $478 \mathrm{~km}$ south of Addis Ababa and $42 \mathrm{~km}$ to the West of Harar Town which is the capital city of both East Hararghe zone and Harar regional state. The total population is estimated to be 199,601 persons, of which estimated urban population is 12,306 and estimated rural population is 187,293. The woreda contains 35 rural kebeles and the altitude ranges from 1,550 to 2,800 meters above sea level. The total area of land in the woreda is 54,494 hectares out of which 20,734 hectare are cultivated and the average land holding per household is 0.6 hectare.

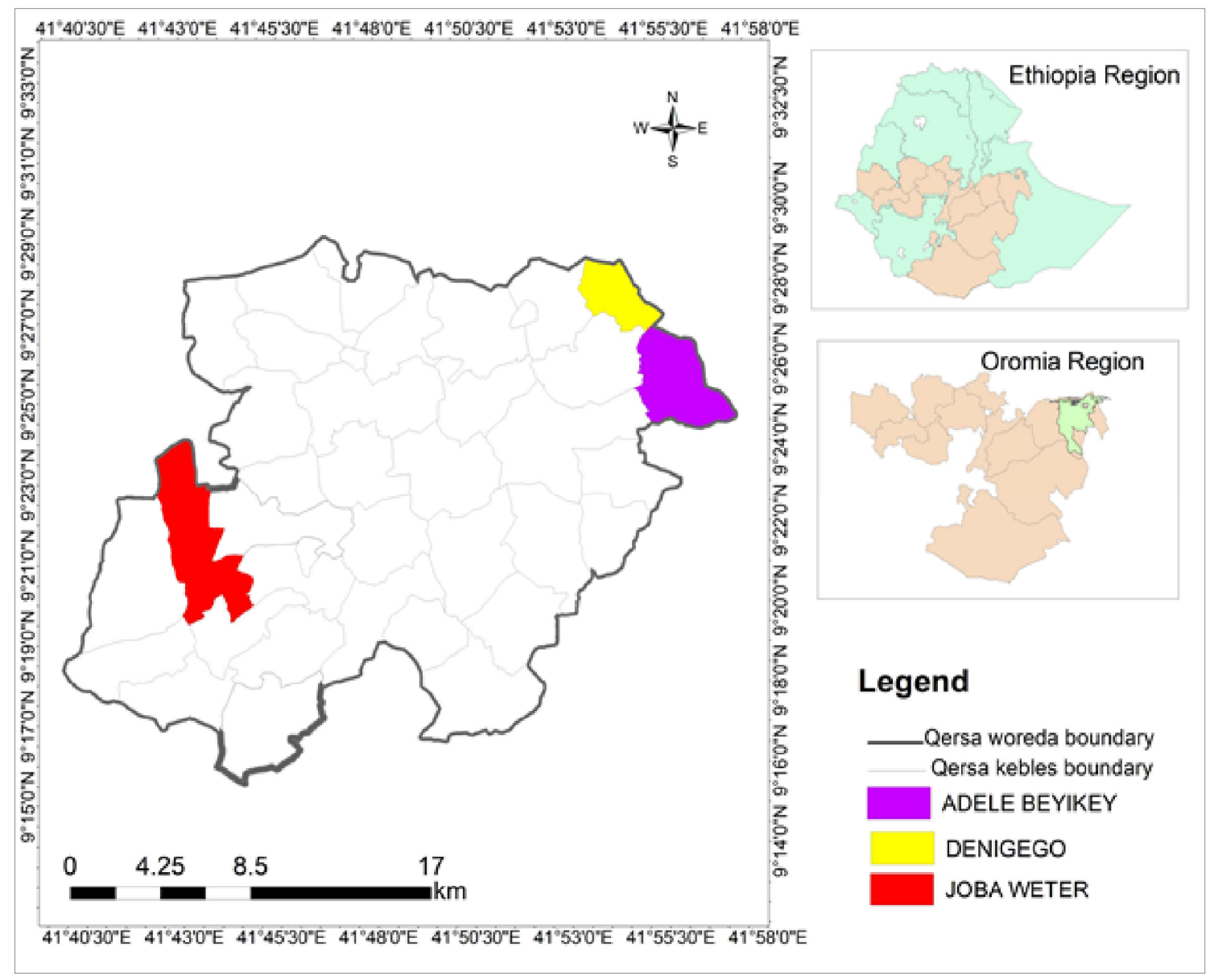

Figure 1. Map of the study area.

\subsection{Method of Sampling Techniques and Sample Size}

Multi-stage sampling procedure was employed. within the first stage, Kersa Woreda was selected purposively because of its area of doubtless existence of non-farm activities and also there was the station of china road-bridge construction's raw material to construct the road and bridge from Dengego to Harar, Dengago to Diredawa and Dengago to Kulubi for five years, in order that rural household had got the opportunities to participate in during this construction and got know-how about masonry, carpenter and plumber. Within the second stage three kebeles were selected purposively 
from the 35 kebeles. The selection criteria for the three kebele were observable based on their proximity to a nearest main road. In third stage, to select sample household from the three kebeles, households were stratified in to two groups in each kebele, that's participant and non-participant, then sample household were selected randomly in each stratum from 178 households using formula by [42] given by

$$
n=\frac{Z^{2} * P * q * N}{(N-1) * e^{2}+Z^{2} * p * q}
$$

\subsection{Sources and Method of Data Collection}

In this study, both of primary and secondary data were used. Primary data were collected by using different mechanisms such as key informant interview, group discussion, and the structured and semi-structured questionnaires. Secondary data were gathered from various sources like Agricultural Offices of districts, Books, and different published materials like articles and Journals.

\subsection{Method of Data Analysis}

\subsubsection{Descriptive Statistics}

According to descriptive statistical methods, categorical variables were analyzed using percentage, frequency and chisquare test while continuous variables were analyzed using mean, standard deviation and t-test.

\subsubsection{Econometric Analysis}

\section{Logit model}

The binary logit model was applied in this study to assist in estimating the probability of rural household participation in non-farm activities. According to [43] the model was employed as follows:

$$
\begin{gathered}
p_{i}=E\left(\frac{Y_{i}}{X_{i}}\right)=\frac{1}{1+e^{-\left(\beta_{0}+\beta_{i}\right)}} \\
P_{i}=E\left(\frac{Y_{i}}{x_{i}}\right)=\frac{1}{1+e^{-z_{i}}}
\end{gathered}
$$

Where $\mathrm{Pi}$ is a probability that a $i^{\text {th }}$ household participated in non-farm activities and ranges from 0 to $1 ; z_{i}$ is a functional form of $\mathrm{n}$ explanatory variables $(\mathrm{X})$ which is expressed as:

$$
Z_{i}=\beta_{0}+\sum_{i=1}^{n} \beta_{i} x_{i}, \mathrm{i}=1,2,3 \ldots \mathrm{n}
$$

Where; $\beta_{0}$ is the intercept and $\beta_{i}$ are the slope parameters in the model. The slope tells how the log-odds in favor of a given household participating in non-farm change as independent variables change. If $P_{i}$ is the probability of a household being in non-farm, then $1-P_{i}$ indicates the probability that a given household did not participate in nonfarm activity, which can be given as:

$$
1-P_{i}=\frac{1}{1+e^{z_{i}}}
$$

Dividing equation (1) by equation (3) gives

$$
e^{z_{i}}=\frac{P_{i}}{1-P_{i}}=\frac{1+e^{z_{i}}}{1+e^{-z_{i}}}
$$

Equation (4) indicates the odds ratio in favor/in terms of a given household participating in non-farm activities. It is the ratio of the probability that a household participated in nonfarm activity to the probability that he/she would not participate. Lastly, the logit model is obtained by taking the natural logarithm of equation (4) as follows:

$$
L i=\ln \left(\frac{P_{i}}{1-P_{i}}\right)=\beta_{0}+\beta_{1} X_{i}
$$

Where; $P_{i}=$ the probability that $\mathrm{Y}=1$ (that a given household participated in non-farm activities; $1-P_{i}=$ the probability that $\mathrm{Y}=0$ (that a given household did not participate in non-farm activities, $\mathrm{Li}=$ the natural $\log$ of the odds ratio or logit;

$\beta_{i}=$ the slope, measures the change in $\mathrm{L}$ (logit) for a unit change in explanatory variables $(\mathrm{X}) ; \beta_{0}=$ the intercept. It is the value of the log odd ratio, $\frac{P_{i}}{1-P_{i}}$ When $\mathrm{X}$ or explanatory variable is zero. Thus, the logit model becomes as the following equation if the error/stochastic terms is taken into account

$$
L_{i}=\beta_{0}+\beta i X_{i}+U_{i}
$$

Propensity score matching model

Propensity score matching (PSM) technique helps to adjust for initial differences between participant and non-participant groups by matching each participant unit to a non-participant unit based on similar observable characteristics by conveniently summarizing the conditional probability of member given pretreatment characteristics [44]. In case of binary treatment of the programme, the treatment indicator $\mathrm{D}_{\mathrm{i}}$ equals 1 if individual $i$ receive treatment and 0 otherwise. In the context of this study, treatment group refers to households who are non-farm activities participant while control group are those who do not participate within the non-farm.

The potential outcomes are then defined as:

$Y_{i}\left(D_{i}\right)$ for each individual $i$, where $i=1,2, \ldots, \mathrm{n}$, then the treatment effect of individual $i$ can be expressed as;

$$
T_{i}=Y_{i}(1)-Y_{i}(0)
$$

This is used only to evaluate potential observable outcomes for each individual and leads to counterfactual problems since other unobservable individual's characteristics which are known as counterfactual outcomes are there. Hence, estimating individual treatment effect $T_{i}$ is not possible. Hence, Average treatment effect on the treated 
(ATT) is become specified as the following equation:

$\mathrm{TT}_{A T T}=E(T \mid D=1)=E[Y(1) \mid D=1]-E[Y(0) \mid D=1]$

Therefore, the counterfactual mean for those being treated represented by $-\mathrm{E}[Y(0) \mid D=1]$, which is actually not observed.

Following [45] and further manipulation, we have the following expressions:

$$
\mathrm{E}[Y(1) \mid D=1]-E[Y(0) \mid D=0]=T_{A T T}+E[Y(0) \mid D=1]-E[Y(0) \mid D=0]
$$

$\mathrm{T}_{\mathrm{ATT}}$ is so called 'self-selection bias; then the true parameters of $\mathrm{T}_{\mathrm{ATT}}$ is only identified if $\mathrm{E}[\mathrm{Y}(0) \mid \mathrm{D}=1]-\mathrm{E}[\mathrm{Y}(0) \mid \mathrm{D}=0]=0$. By rearranging equation above, we have:

$$
[\mathrm{Y}(0) \mid \mathrm{D}=1]-\mathrm{E}[\mathrm{Y}(0) \mid \mathrm{D}=0]=0=\mathrm{T}_{\mathrm{ATT}}=\mathrm{E}[\mathrm{Y}(1)-\mathrm{Y}(0)]
$$

Common support region given by: overlap $0<\mathrm{p}(\mathrm{D}=1 / \mathrm{X})<1$

Ultimately, the general PSM model specified as a fallow:

$$
Y_{A T T}^{p s m}=E_{p(X) \mid D=1}\{E[Y(1) \mid D=1, P(X)]-E[Y(0) \mid D=0, P(X)]\}
$$

This implies that PSM estimator is mean difference in outcomes over the common support region which is appropriately weighted by the propensity score distribution of participants.

\subsection{Description of Variables That Were Used in the Analysis and Their Measurement}

Dependent variable: participation in nonfarm activities. It is a dummy variable for household who participate were taking " 1 " and " 0 " for non-participant rural household. within the study, rural households were asked if in the past 12 months do any member of the household has operated in any form of non-farm activity such as his or her own business, petty trade, or worked as a self-employed or craftsman, carpenter, woody work, charcoal and also masonry, plumber and carpenter.

Outcome variable: Household wellbeing: in this study wellbeing were measured by using consumption expenditure per adult equivalent. Total annual household consumption expenditure measured as the total annual expenditure for all goods and services consumed by the household in a year in terms of Ethiopian birr. In this study in order to convert total consumption expenditure into consumption expenditure per adult equivalent, which is the most commonly used definition given by the Organization for Economic Cooperation and Development, because of its simplicity of using and wide familiarity [46]. This scale is expressed as follows:

$$
E X P_{e q}=E X P / n^{0.7}
$$

Where, $\mathrm{EXP}=$ total household expenditure, and $\mathrm{n}=$ household size, $0.7=$ exponential formation representing other adults in a particular household

In this study the use of consumption expenditure per adult equivalent to measure wellbeing of household is based on evidence existence of various researches which measured welfare/wellbeing using through consumption expenditure per adult equivalent. According to [47] welfare is measured based on consumption expenditure per adult equivalent because household's income is hard to measure in less developed countries as a large amount of their income comes from self-employment. There were also previous researches that was used consumption per adult equivalent to measure wellbeing in Ethiopia includes [48, 49, 50]. Similarly in line with [10] economic wellbeing is measured by annual total consumption expenditure and food shortage status.

\section{Results and Discussion}

\subsection{Descriptive Statistics Results}

The descriptive statistics showed that the existence of a significant mean difference between non-farm participant and non-participant categories. Student t-test was employed to test weather significance difference between participant and nonparticipant in nonfarm activities based on continuous variables. Continuous variables including adult equivalent size, farm experience, and tropical livestock unit, age of household head, cultivated land size and distance from main road were significantly difference between participant and non-participant in non-farm work at various probability level (Table 1).

Table 1. Summary statistics of continuous variables used in the analysis.

\begin{tabular}{llllllll}
\hline \multirow{2}{*}{ Variables } & \multicolumn{2}{l}{ Non-participant } & participant & \multicolumn{2}{c}{ Combined } & Difference \\
\cline { 2 - 7 } & Mean & Std Dev & Mean & Std Dev & Mean & Mean & T-value \\
\hline Age of HH head & 41.85 & 9.45 & 35.11 & 6.85 & 38.45 & 6.74 & $5.4^{* * *}$ \\
Equivalent adult & 6.28 & 2.54 & 6.2 & 2.29 & 6.23 & -0.101 & -0.27 \\
Dependency ratio & 0.401 & 0.286 & 0.444 & 0.348 & 0.422 & -0.0425 \\
Cultivated land & 0.775 & 0.428 & 0.55 & 0.402 & 0.661 & 0.229 & 0.893 \\
Farm experience & 20.2 & 8.53 & 10.51 & 7.74 & 15.34 & 9.653 \\
Tropical livestock & 1.85 & 1.41 & 0.7 & .099 & 1.275 & 1.152 & $3.68^{* *}$ \\
Distance from main road & 0.63 & 0.499 & 0.297 & 0.1695 & 0.464 & 0.333 \\
\hline
\end{tabular}

Note: $* * *$ and $* *$ significant at $1 \%$, and $5 \%$ respectively. Source own survey, (2019). 
On the other hand Chi-square test was used to show significance among categorical variables. From seven categorical variables access to nonfarm training, access to irrigation, and access to improved seed was found to have significant association with participant households at various probability levels (Table 2).

Table 2. Summary statistics of categorical variables used in the analysis.

\begin{tabular}{|c|c|c|c|c|c|c|c|}
\hline & \multicolumn{2}{|c|}{ Variables dummy } & \multicolumn{2}{|c|}{ Non-participant } & \multicolumn{2}{|c|}{ participant } & \multirow{2}{*}{$\begin{array}{l}\text { Total } \\
\text { Chi-square }\end{array}$} \\
\hline & $\mathbf{N}$ & $\%$ & $\mathbf{N}$ & $\%$ & $\mathbf{n}$ & $\%$ & \\
\hline \multicolumn{8}{|l|}{ Sex } \\
\hline Male $=1$ & 40 & 55.56 & 59 & 55.67 & 99 & 55.61 & 0.001 \\
\hline \multicolumn{8}{|l|}{ Education status } \\
\hline Yes $=1$ & 16 & 18.7 & 56 & 31.5 & 72 & 40.5 & $37.32^{* * *}$ \\
\hline Otherwise $=0$ & 73 & 41.01 & 33 & 18.54 & 106 & 59.55 & \\
\hline Yes $=1$ & 28 & 15.73 & 43 & 24.16 & 71 & 39.89 & $5.27^{* *}$ \\
\hline $\mathrm{No}=0$ & 61 & 34.3 & 46 & 25.84 & 107 & 60.11 & \\
\hline \multicolumn{8}{|l|}{ Use of } \\
\hline irrigation Yes=1 & 53 & 29.79 & 29 & 16.29 & 82 & 46.1 & $13.02^{* * *}$ \\
\hline $\mathrm{No}=0$ & 36 & 20.22 & 60 & 33.71 & 96 & 53.93 & \\
\hline \multicolumn{8}{|l|}{ Access to credit } \\
\hline Yes $=1$ & 18 & 10.11 & 37 & 20.79 & 55 & 30.9 & $6.04^{* *}$ \\
\hline $\mathrm{No}=0$ & 71 & 39.89 & 52 & 29.21 & 123 & 69.1 & \\
\hline Yes $=1$ & 25 & 14.04 & 50 & 27.09 & 75 & 42.13 & $14.41^{* * *}$ \\
\hline $\mathrm{No}=0$ & 64 & 35.9 & 39 & 21.9 & 103 & 57.87 & \\
\hline \multicolumn{8}{|l|}{ Use of fertilizer } \\
\hline Yes $=1$ & 79 & 44.38 & 81 & 45.51 & 160 & 89.89 & 0.25 \\
\hline $\mathrm{No}=0$ & 10 & 5.62 & 8 & 4.49 & 18 & 10.11 & \\
\hline
\end{tabular}

Note: $* * *$ and $* *$ significant at $1 \%$, and $5 \%$ respectively. Source own survey, (2019).

\subsection{Propensity Score Estimation}

For this study, thirteen explanatory variables were selected to be included in the logistic regression model based on previous studies and theories. Looking at the standard errors and estimated coefficients given in Table 3, education status of the household head, adult equivalent size, farm experience and access to nonfarm training has positive and significant effect on the decision of the non-farm participation. However, Age of household head, cultivable land owned, and tropical livestock unit has negative and significant effect on the non-farm participation decision.

Table 3. Determinant participation results of estimated propensity scores.

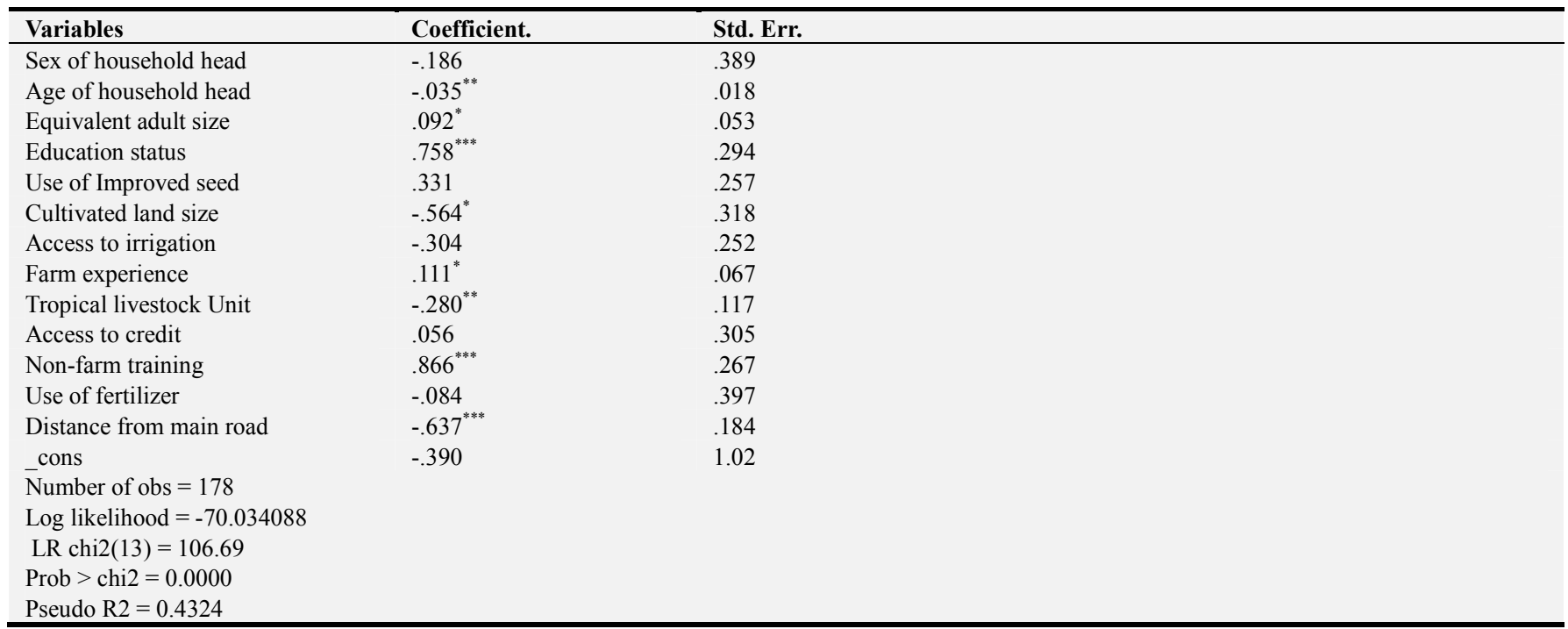

Note: $* * *$ and $* * *$ denote statistical significance at $10 \%, 5 \%$ and $1 \%$ respectively.

Source: Own estimation (2019). 


\subsubsection{Matching Estimated Propensity Score for Treated and Controlled Groups}

This technique applies the common support region, which is the area that contains the minimum and maximum propensity scores of treatment and control group households respectively. As shown in Table 4, based on the minima and maxima criterion, the common support region lies between 0.03 and 0.93 . In other words, households with estimated propensity scores less than 0.03 and greater than 0.93 were not taken into consideration for the matching exercise and take away from the sample. As a result of this restriction on the common support condition, out of 178 sampled households 19, 27, 23 were taken away from the analysis nearest neighbor, radius and kernel matching respectively and considered as the opportunity cost of using matching estimator.

Table 4. Sample Household Group Observation based on estimated propensity scores distribution.

\begin{tabular}{llllll}
\hline & $\boldsymbol{n}$ & Mean & Std.Dev. & Min & Max \\
\hline Participants Households & 89 & 0.73 & 0.23 & 0.03 & 0.99 \\
Non-participants Households & 89 & 0.27 & 0.27 & 0.02 \\
Total Households & 178 & 0.5 & 0.34 & 0.93 & 0.02 \\
\hline
\end{tabular}

Source: Own estimation based on survey 2019.

\subsubsection{Treatment Effect on the Treated (ATT)}

The estimation result provided in Table 5 gives supportive evidence of statistically significant effect of nonfarm activities on household consumption expenditure per adult equivalent which is an important proxy to household wellbeing. After controlling for pre intervention differences in characteristics of the nonfarm participant and non-participant households, it was found that, on average, consumption expenditure per adult equivalent is higher for households who participating in nonfarm activities than non-participant households. This implies that nonfarm intervention plays a vital role in improving wellbeing of rural households in study area as the treated household's consumption expenditure per adult equivalent is increased by 29.1 to 36.7 percent as compared to the controlled households. In other hand the magnitude of the ATT ranges from 1825.42 Birr to 2271.8 Birr for the different methods of PSM.

In order to check robustness for the ATT (Average treatment effect on treated) evaluation using PSM, we estimated the impact using the radius and kernel Method was used to estimate impact of non-farm activities on consumption expenditure per adult equivalent. Both approaches support the estimation results of nearest neighbor method. Radius matching method provides the highest ATT estimation amounts to 2,271.8 Birr, which is strongly significant at 1 percent significance level. In addition, the kernel method supports the estimates of the two matches with ATT amount of Birr 1959.4. Generally, the study results in Table 5 show that participated in nonfarm activities had brought positive significant impact on household consumption expenditure per adult equivalent in study area. This shows non-farm activities can be used to smoothen household consumption in case of wellbeing. This result similar with the study which states participation in non-farm activities has positive effect on welfare/wellbeing of households [10, 32, 51, 52]. And also the study by the [53] reaffirms that income from non-farm sector assist the small-farm households to become food secured and to improve their wellbeing.

Table 5. PSM -based average treatment effects of non-farm activities on consumption expenditure per adult equivalent.

\begin{tabular}{llllll}
\hline Matching algorithm & Treated & Controls & Difference & S.E. \\
\hline Nearest neighbour & 8107.3 & 6281.88 & 1825.42 & 789.58 & $2.312^{* *}$ \\
Radius matching & 8468 & 6196.2 & 2271.8 & 559.53 & $4.06^{* * *}$ \\
Kernel matching & 8667.9 & 6708.5 & 1959.4 & 319.31 \\
\hline
\end{tabular}

Note: $* *, * * *$ indicates significance at $10 \%, 5 \%$ and $1 \%$ probability level respectively.

Source: Own estimation based on survey 2019.

\section{Conclusion and Recommendation}

The study was analyzed the impact of non-farm activities on wellbeing of household in Kersa district. Data analysis was made using propensity score matching model as econometric analysis mainly to avoid self-selection problem. Analysis result shows that the likelihoods of participation in non-farm work are influenced by variables such as age and educational status of the household head, adult equivalent size, and cultivable land size, distance from main road, farm experience and non-farm training. The impact estimation from the propensity score matching suggests that participation in non-farm activities have significantly higher consumption per adult equivalent than non-participant. This finding indicates that non-farm activities are effective in improving the wellbeing of the rural community. The results of sensitivity analysis show that estimated ATT for consumption expenditure per adult equivalent (the outcome variable) is insensitive which clearly indicates its robustness.

Based on study findings, some basic future policy implications should developed: The study found that nonfarm activities had significantly increased household consumption per adult equivalent. As a result, the government and other stakeholders responsible for the development of rural area in the state should provide an encouraging indicator of non-farm activities to rural 
residents. In addition, rural development agent should give an attention to the factors that contribute to the extent of nonfarm activities.

\section{References}

[1] IFAD (International Fund for Agricultural Development) (2011) Rural poverty portal., http://www.ruralpovertyportal.org/web/guest/region/home/tag s/Africa.

[2] MOARD (Ministry of Agriculture \& Rural Development) (2010). Ethiopia's agricultural sector policy and investment framework 2010-2020. Addis Ababa, Ethiopia: Federal Democratic Republic of Ethiopia (FDRE).

[3] Diao, X., Thurlow, J., Benin, S., \& Fan, S. (Eds.). (2012). Strategies and priorities for African agriculture: Economywide perspectives from country studies. Intl Food Policy Res Inst.

[4] Tittonell, P., \& Giller, K. E. (2013). When yield gaps are poverty traps: The paradigm of ecological intensification in African smallholder agriculture. Field Crops Research, 143, 76-90.

[5] Tsega Adego, Belay Simane \& Getachew A. Woldie (2019) The impact of adaptation practices on crop productivity in northwest Ethiopia: an endogenous switching estimation, Development Studies Research, 6: 1, 129-141, DOI: 10.1080/21665095.2019.1678186.

[6] Echebiri R, Onwusiribe C, Nwaogu D (2017). Effect Of Livelihood Diversification On Food Security Status Of Rural Farm Households In Abia State Nigeria. Scientific Papers Series Management, Economic Engineering in Agriculture and Rural Development 17 (1): 159-166.

[7] Prowse M (2015). The Determinants of Non-Farm Income Diversification in Rural Ethiopia. Journal of Poverty Alleviation and International Development 6 (1): 109-130.

[8] Abduselam, A. M., Badassa, W. ., \& Milkessa, T. C. (2018). Impact of Productive Safety Net Programme on Food Security: The Case of Babile District, Somali Regional State, Ethiopia: Food Science and Quality Management, ISSN 2224-6088 (Paper) ISSN 2225-0557 (Online) Vol.81, 2018.

[9] FAO, IFAD and WFP. 2013. The State of Food Insecurity in the World 2013. The multiple dimensions of food security. Rome, FAO.

[10] AZIZ, S. A., SIDIQUE, S. F., \& SAID, R. (2017). Determinants and Effects of Non-Farm Enterprise Diversification on Household Economic Wellbeing in Rural Nigeria. International Journal of Economics \& Management, $11(1)$.

[11] Haggblade, S., Hazell, P., \& Reardon, T. (2010). The rural non-farm economy: Prospects for growth and poverty reduction. World development, 38 (10), 1429-1441.

[12] Davis, J. \& Pearce, D. (2001). The Non-Agricultural Rural Sector in Central and Eastern Europe. Department for International Development (DFID)/World Bank. Collaborative Program for Rural Development. Natural Resources Institute Report No. 2630.
[13] Emanuel, E. (2011). Rural Livelihood Diversification and Agricultural household welfare in Ghana. J. Develop. Agric. Econ. 3 (7): 325-334.

[14] CSA. (2013). National Labor Force Survey Report, Central Statistical Agency of Ethiopia; Addis Ababa, Ethiopia.

[15] UNDP (2015) African economic outlook: Ethiopia., http://www.africaneconomicoutlook.org/fileadmin/uploads/ae o/2015/CN_data/CN_Long_EN/Ethiopia_GB 2015.pdf.

[16] Teshome, J., Bayisa, Z., \& Keno, T. (2015). Fostering Rural Employment through Creating Rural Non-Farm Activities (RNA) and Household Jobs in Haramaya, Kersa, and Babile Woredas of Eastern Hararghe Zone, Oromia National Regional State, Ethiopia.

[17] World Bank (2019). Seventh Ethiopia Economic Update: Special Topic: Poverty and Household Welfare in Ethiopia, 2011-2016 (English); World Bank Group: Washington, DC, USA, 2019; Availableonline:http://documents.worldbank.org/curated/en/4 32421554200542956/Special-Topic-Povertyand-HouseholdWelfare-in-Ethiopia-2011--2016 (accessed on 28 February 2020).

[18] Adem, M., Tadele, E., Mossie, H., \& Ayenalem, M. (2018). Income diversification and food security situation in Ethiopia: A review study. Cogent Food \& Agriculture, 4 (1), 1513354.

[19] African Development Bank. (2014). Africa Food Security Brief: Special focus on climate Africa Food Security change Impacts. Vol. 5: Statistics Department. April 2014.

[20] WFP \& CSA (2014). Comprehensive food security and vulnerability analysis in Ethiopia. Ethiopia: Addis Ababa.

[21] Sewnet, Y. (2015). Causes and coping mechanisms of food insecurity in rural Ethiopia. Agricultural and Biology Journal of North America, 6 (5), 123-133.

[22] Welteji, D., Mohammed, K., \& Hussein, K. (2017). The contribution of Productive Safety Net Program for food security of the rural households in the case of Bale Zone, Southeast Ethiopia. Agriculture \& Food Security, 6 (1), 53.

[23] MoARD (2010). Ethiopia's Agriculture Sector Policy and Investment Framework: Ministry of Agriculture and Rural Development Ten-year Road Map (2010-2020).

[24] CSA (Central Statistical Agency). (2012). Population size by Age, Area and Density by Region, Zone and Woreda, Addis Ababa, Ethiopia.

[25] FAO (2015). The State of Food and Agriculture Social protection and agriculture: Breaking the cycle of rural poverty. Food and agriculture organization of the United Nations Rome, 2015.

[26] Fao, W. (2010). The state of food insecurity in the World 2010, Addressing food insecurity in protracted crises. WFP, FAO. Journal of Rural Studies, 29, 101-112.

[27] Weldegebriel, Z. B. (2015). Rural Non-Farm Diversification in Ethiopia: What Determines Participation and Returns?

[28] Esubalew Y and Daniel M (2019). Impact of Livelihood Diversification on Rural Household Food Security: Evidence from Goncha-Siso-Enesie Destrict of Amhara Regional State, Ethiopia. 
[29] FDRE. (2015). Federal democratic republic of Ethiopia; The Second Growth and Transformation Plan (GTP II) (2015/162019/20) (Draft) September 2015Addis Ababa.

[30] Loening, J., Rijkers, B., \& Soderbom, M. (2008). Nonfarm microenterprise performance and the investment climate: evidence from rural Ethiopia. The World Bank.

[31] Block, S. \& Webb, P (2001). The dynamics of livelihood diversification in post-famine Ethiopia. FoodPolicy 2001, 26, $333-350$.

[32] Ali, M., \& Peerlings, J. (2012). Farm households and nonfarm activities in Ethiopia: does clustering influence entry and exit? Agricultural Economics, 43 (3), 253-266.

[33] Zerai, B., \& Gebreegziabher, Z. (2011). Effect of nonfarm income on household food security in eastern Tigrai, Ethiopia: An entitlement approach. Food Science and Quality Management, 1 (10), 1-23.

[34] Yizengaw, B. (2014). Determinants of household income diversification and its effect on food security status in rural Ethiopia: Evidence from Ethiopia longitudinal rural household survey (Doctoral dissertation, Doctoral dissertation, Master's thesis, Addis Ababa University, Addis Ababa, Ethiopia).

[35] Gemechu, F., Zemedu, L., \& Yousuf, J. (2016). Determinants of farm household food security in Hawi Gudina district, West Hararghe zone, Oromia Regional National State, Ethiopia. Journal of Agricultural Extension and Rural Development, 8 (2), 12-18.

[36] Ayana, A., \& Ermias G. (2019). The Impact of Off-farm Activities on Rural Household Income in Wolaita Zone, Southern Ethiopia. Journal of World Economic Research. Vol. 8, No. 1, 2019, pp. 8-16. doi: 10.11648/j.jwer.20190801.12.

[37] Demissie, A., \& Legesse, B. (2013). Determinants of income diversification among rural households: The case of smallholder farmers in Fedis district, Eastern Hararghe zone, Ethiopia. Journal of Development and Agricultural Economics, 5 (3), 120-128.

[38] Gagabo, T. (2014). Analyzing the determinants and the effects of income diversification in rural Ethiopia. International social science.

[39] Tefera, T. L., Perret, S., \& Kirsten, J. F. (2004). Diversity in livelihoods and farmers' strategies in the Hararghe Highlands, eastern Ethiopia. International Journal of Agricultural Sustainability, 2 (2), 133-146.

[40] Teshome, J., Bayisa, Z., \& Keno, T. Fostering Rural Employment through Creating Rural Non-Farm Activities (RNA) and Household Jobs in Haramaya, Kersa, and Babile Woredas of Eastern Hararghe Zone, Oromia National Regional State, Ethiopia.
[41] NCA (nutrition causal analysis) (2014). East Hararghe Zone, Fedis and Kersa Woredas, Ethiopia.

[42] Kothari, C. R., 2004. Research methodology: Methods and techniques. New Age International.

[43] Gujarati, D. N. (1995). Basic Econometrics. Second Edition. New York, MacGraw Hill, Inc. 838p.

[44] Rosenbaum PR, Rubin DB (1983) The central role of the propensity score in observational studies for causal effects. Biometrika 70 (1): 41-55,

https://doi.org/10.1093/biomet/70.1.41

[45] Caliendo, M. and Kopeinig, S., 2008. Some practical guidance for the implementation of propensity score matching.

[46] Grootaert, C. (1986). Measuring and analyzing levels of living in developing countries: An annotated questionnaire, World Bank living standard measurements study working paper no. 24.

[47] Ahmed, M. H., \& Mesfin, H. M. (2017). The impact of agricultural cooperatives membership on the wellbeing of smallholder farmers: empirical evidence from eastern Ethiopia. Agricultural and Food Economics, 5 (6), 1-20.

[48] Hagos, F., \& Mamo, K. (2014). Financial viability of groundwater irrigation and its impact on livelihoods of smallholder farmers: The case of eastern Ethiopia. Water Resources and Economics, 7, 55-65.

[49] Abro ZA, Alemu BA, Hanjra MA (2014) Policies for agricultural productivity growth and poverty reduction in rural Ethiopia. World Dev 59: 461-474, http://dx.doi.org/10.1016/j.worlddev.2014.01.033.

[50] Naznin Sultan, Md. Elias Hossain, Md. \& Khairul Islam (2015). Income Diversification and Household Well-Being: A Case Study in Rural Areas of Bangladesh. International Journal of Business and Economics Research. Vol. 4, No. 3, 2015, pp. 172-179. doi: 10.11648/j.ijber.20150403.20.

[51] Ibrahim, M. K., Adejoh, S. O., \& Shaibu, U. M. (2017). Impact of Off-farm Sector Involvement on Welfare of Rural Households in Nigeria: Department of Agricultural Economics and Extension, Kogi State University, Nigeria.

[52] Osarfo, D., Senadza, B., \& Nketiah-Amponsah, E. (2016). The Impact of Nonfarm Activities on Rural Farm Household Income and Food Security in the Upper East and Upper West Regions of Ghana.

[53] IFAD (2011), "Non-Farm Opportunities from Smallholder Agriculture", Conference on New Directions.://www.ifad.org/events/agriculture/doc/papers/nonfarm.pdf. 